\title{
MECHANICAL PROPERTIES OF ALUMINIUM BRACKET STRENGTHENING
}

\begin{abstract}
A. AMBROZIAK ${ }^{1}$
The aim of the research is laboratory investigation of aluminium brackets employed to fasten lightweight curtain walls to building facilities. Tensile loads perpendicular to end plates (vertical) were applied here. The author focused on the solutions intended to increase the load-carrying capacity of aluminium brackets applying the plain washer form A (DIN 125; ISO 7089), plain washer with an outer diameter about 3d (DIN 9021; ISO 7093) and additional cover plates (straps) in the location of bolt anchoring on the base plate. The aluminium brackets were tested on a steel base and concrete substrate. The flexibility of anchoring strongly affects the increase of the end plate middle point displacement and movable crosshead displacement.
\end{abstract}

Keywords: aluminium bracket, cover plates, mechanical properties, EN AW-6060 T66

\section{INTRODUCTION}

Aluminium brackets form a group of the most popular elements applied to fasten lightweight curtain walls to building facilities in civil engineering (e.g. in mullion-transom wall systems to connect box-section aluminium profiles to structures, see Fig. 1). Curtain walls are complex systems composed of separate components (see e.g. Kazmierczak [8]). One of the most important design problems of curtain walls is a proper choice of a bracket and its fastening to a building structure. Improper bracket design and/or its fastening may trigger problems with curtain walls (see e.g. Tovarović et al. [9]). Moreover, inadequate support of glass façade elements eventually brings about the extreme danger to life and property. Ambroziak et al. [1] have undertaken numerical and analytical investigations of aluminium bracket strengthening by additional cover plates (straps) in

\footnotetext{
${ }^{1}$ DSc., PhD., Eng., Prof. GUT, Gdansk University of Technology, Faculty of Civil and Environmental Engineering, St. Gabriela Narutowicza 11/12, 80-233 Gdansk, Poland, e-mail: ambrozan@pg.edu.pl, ORCID: 0000-0002-7735-7863
} 
the case of insufficient load-bearing capacity and stiffness due to design loads. The proposed research addresses laboratory tests to experimentally assess the increase of bearing capacity of the aluminium bracket applied to fasten lightweight curtain walls to building facilities.

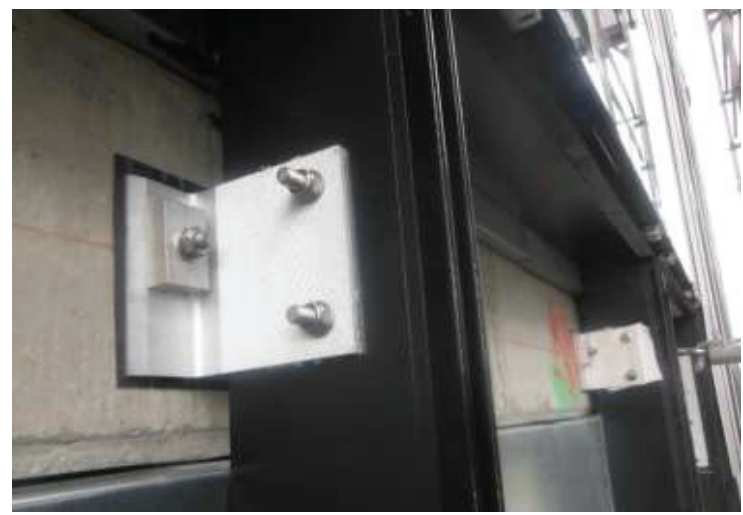

Fig. 1. View on fixed aluminium brackets in mullion-transom wall system
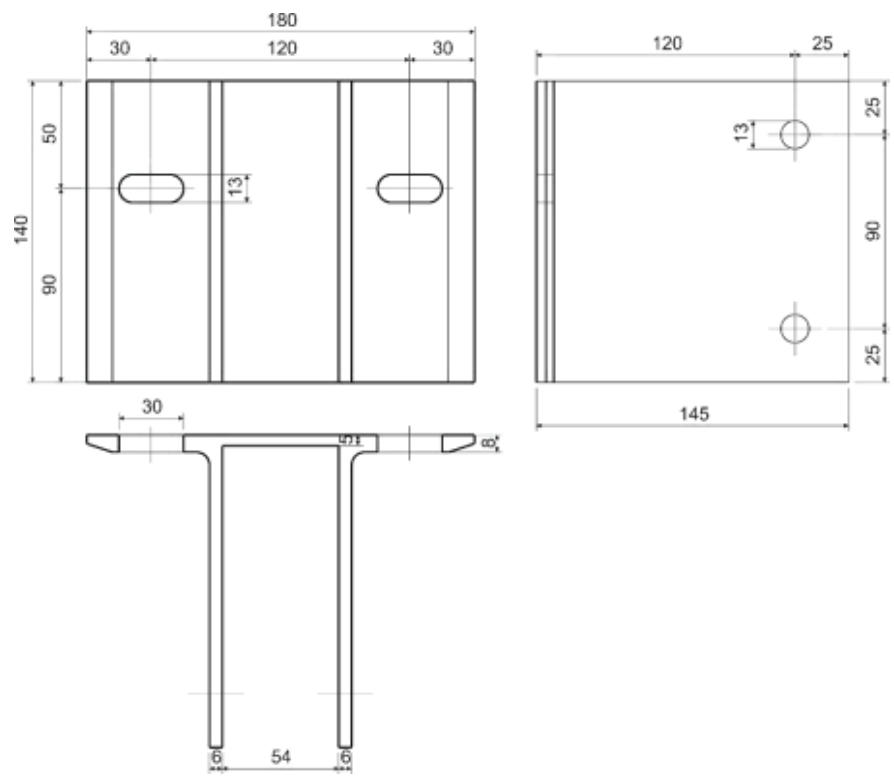

Fig. 2. View and cross-section of analysed aluminium bracket 


\section{MATERIALS}

An investigated aluminium bracket consists of an end plate and two cantilever plates (Fig. 2). The end plate is $180 \mathrm{~mm}$ wide and $140 \mathrm{~mm}$ high, showing various thickness: $8 \mathrm{~mm}$ and $5 \mathrm{~mm}$ (in the middle of the end plate). The cantilever plate of $6 \mathrm{~mm}$ thickness is $145 \mathrm{~mm}$ wide and $140 \mathrm{~mm}$ high, includes two normal holes of a $13 \mathrm{~mm}$ diameter. Two oval holes (13 $\mathrm{mm}$ by $30 \mathrm{~mm}$, Fig. 2) in the end plate are provided to fasten the aluminium bracket to the building structure.

Table 1. Mechanical properties of EN AW-6060 T66 according to EN 755-2 [5]

\begin{tabular}{|c|c|}
\hline properties & values \\
\hline Proof stress $\mathrm{R}_{\mathrm{e} 0.2}[\mathrm{MPa}]$ & 150 \\
\hline Tensile strength $\mathrm{R}_{\mathrm{m}}[\mathrm{MPa}]$ & 195 \\
\hline Elongation min. & 8 \\
\hline Elongation max. & 8 \\
\hline Brinell hardness & 65 \\
\hline $\begin{array}{c}\text { B-value in Ramberg-Osgood expression for plastic } \\
\text { analysis }\end{array}$ & 18 \\
\hline
\end{tabular}

Table 2. Technical data of a single anchor in non-cracked normal concrete

\begin{tabular}{|c|c|}
\hline properties & values \\
\hline Nominal drill hole diameter $\mathrm{d}_{0}[\mathrm{~mm}]$ & 12 \\
\hline Min. member thickness $\mathrm{h}_{\min }[\mathrm{mm}]$ & 120 \\
\hline Effective anchorage depth $\mathrm{h}_{\mathrm{ef}}[\mathrm{mm}]$ & 70 \\
\hline Installation torque $\mathrm{T}_{\text {inst }}[\mathrm{Nm}]$ & 60 \\
\hline Pteel failure - characteristic resistance $\mathrm{N}_{\mathrm{Rk}, \mathrm{s}}[\mathrm{kN}]$ & 44.3 \\
\hline $\begin{array}{c}\text { Pullout failure }- \text { characteristic resistance in uncracked concrete } \mathrm{C30/37} \\
\mathrm{N}_{\mathrm{Rk}, \mathrm{p}}[\mathrm{kN}]\end{array}$ & 26.8 \\
\hline Displacement - factor for tensile load $\delta_{\text {No }}[\mathrm{mm} / \mathrm{kN}]$ & $0.06-0.14$ \\
\hline
\end{tabular}

In laboratory tests two variants of bases (steel plate and concrete foundation) were applied, see Fig. 3. In the first variant, two A4-70 stainless steel bolts M12 (diameter of $12 \mathrm{~mm}$ ) were used to fasten the aluminium bracket to the steel plate of $25 \mathrm{~mm}$ thickness. In the concrete foundation case two bolt anchors made of A4 stainless steel were applied. The anchoring process of the aluminium bracket on concrete consists of several actions. First of all the drill hole was made, next, the anchor was hammered in, finally, the nut was tightened with a controlled torque equal $60 \mathrm{Nm}$ (Table 2). Reinforced concrete elements were applied of strength class C30/37 (compressive strength: 30MPa cylinder and 37 cube according to standard EN206 [7]), their dimensions are: thickness $20 \mathrm{~cm}$, width $38 \mathrm{~cm}$ and length $70 \mathrm{~cm}$. The laboratory tests were focused on solutions to increase the loadcarrying capacity of aluminium brackets due to three types of washers applied in the location of bolt anchoring on an end plate, see Fig. 2. The applications were tested of the A4 stainless steel flat 
washer form A (DIN 125; ISO 7089), A4 stainless steel flat washer with an outer diameter about 3d (DIN 9021; ISO 7093, called large washer) and additional aluminium cover plates (straps), see Fig. 4. The laboratory-tested concept of a strengthened end plate of the aluminium bracket by additional cover plates (straps) can be compared with the concept of a reinforced T-stub flange with backing plates (see e.g. Zoetemeijer [3], Nair et al. [4]). The aluminium bracket and cover plates (straps) are made of EN AW-6060 T66 aluminium alloy. The material parameters for the EN AW-6060 T66 aluminium alloy can be found in civil engineering standards. Table 1 includes major mechanical properties of the EN AW-6060 T66 aluminium alloy due to wall thickness from 3 to $25 \mathrm{~mm}$. In the case of concrete foundation, the M12 bolt anchors were installed in a drilled hole in a concrete element and anchored by torque-controlled expansion. The base technical data due to torquecontrolled expansion anchor dedicated to concrete is available in Table 2.
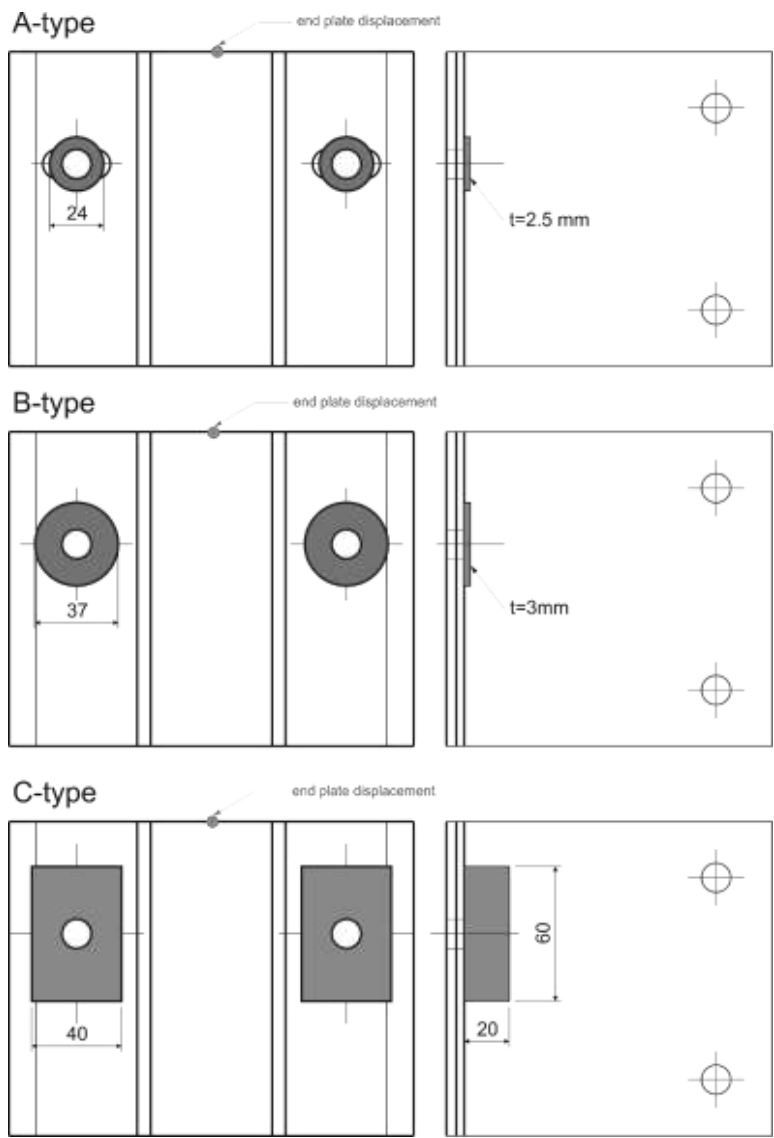

Fig. 3. Analysed aluminium bracket with plain washers and cover plates (straps) 


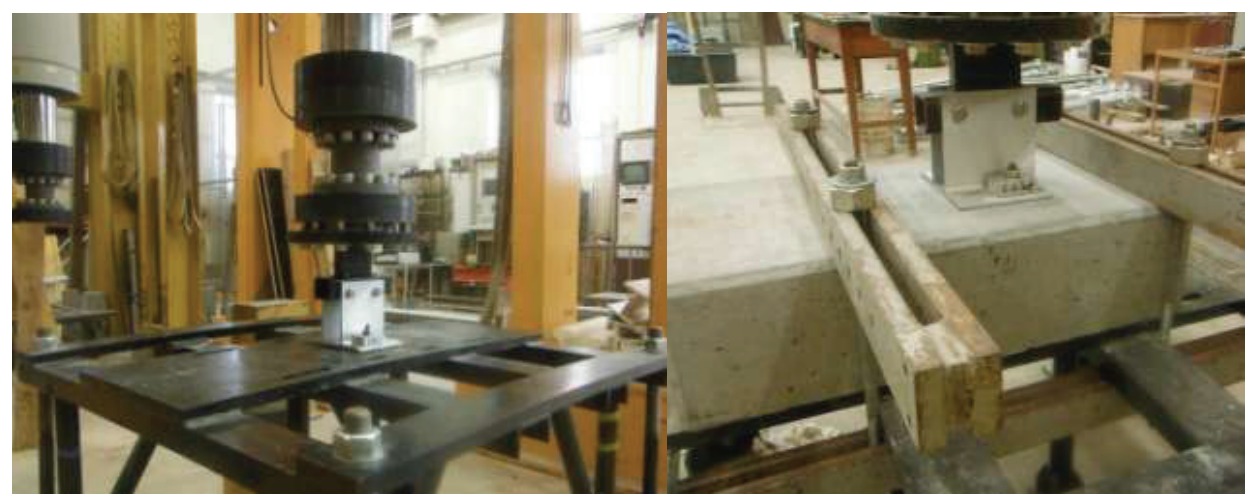

Fig. 4. Laboratory test stands for steel and concrete bases

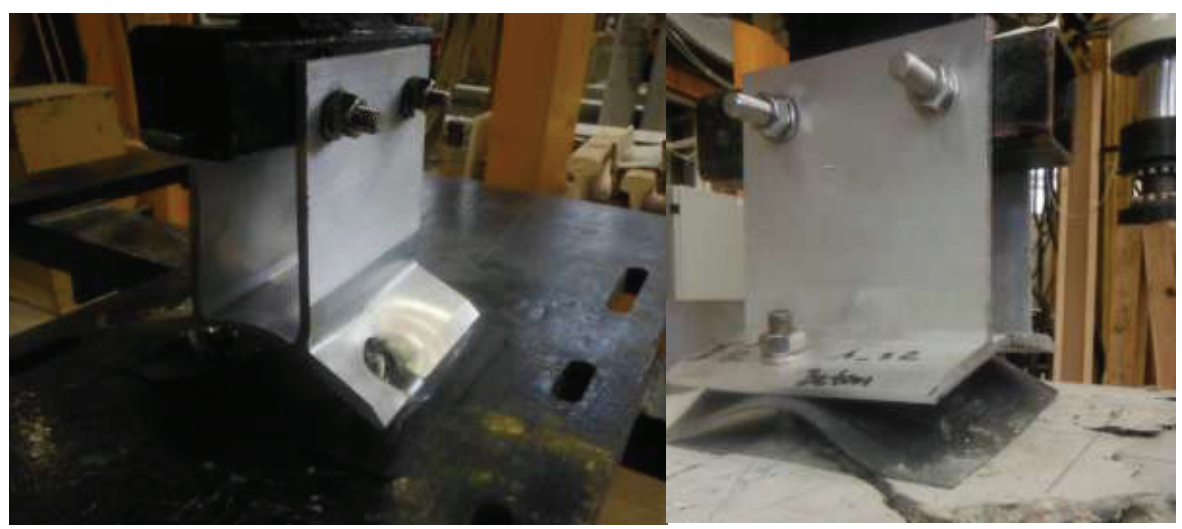

Fig. 5. Damaged aluminium brackets after tensile tests

\section{LABORATORY TESTS}

The tensile loads perpendicular to the end plate (vertical) were applied in laboratory tests by means of the computer-controlled Zwick testing machine (Fig. 4). The aluminium brackets were subjected to tension with a constant loading speed (force controlled) equal $5000 \mathrm{~N} / \mathrm{min}$ (according to the ETAG 034 guideline [6]. All tests were performed at room temperature (about $20^{\circ} \mathrm{C}$ ). First of all, the experiments were performed with a constant loading speed to failure of the aluminium brackets or damage of anchoring under the steel base (type A1, B1, and C1) and concrete base (type A2, B2, and $\mathrm{C} 2$ ), see Fig. 5. The diagram of tensile force vs displacement of movable crosshead up to rupture of the aluminium bracket is shown in Fig. 6. The values of rupture forces obtained in the aluminium bracket laboratory tests are shown in Table 3. It should be noted, that in the case of steel 
base the possibilities are damage of the end plate (see Fig. 5a) or failure of steel bolts. On the other hand, in the case of concrete foundations, rupture forces are determined by the strength of bolt anchoring (without cracks and tears of aluminium bracket), see Fig. 5 b.

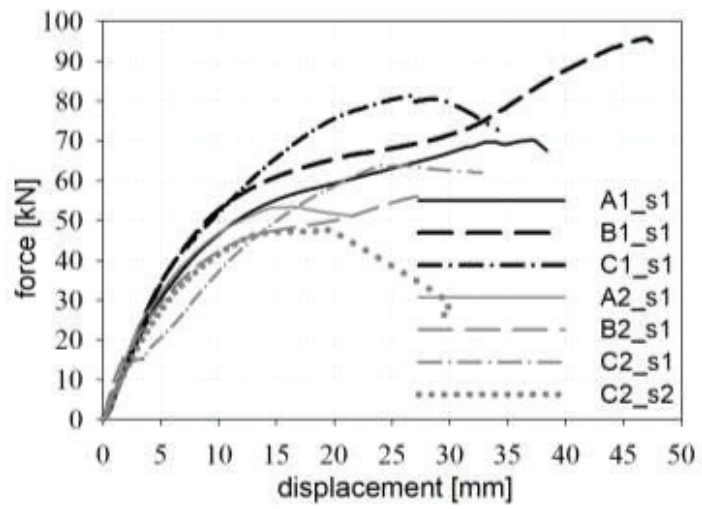

Fig. 6. Tensile force versus displacement up to rupture of aluminium bracket

Table 3. Rupture forces $[\mathrm{kN}]$ of aluminium bracket

\begin{tabular}{|c|c|c|c|}
\hline steel base & value & concrete base & value \\
\hline A1_s1 & 70.3 & A2_s1 & 53.4 \\
\hline B1_s1 & 95.8 & B2_s1 & 56.2 \\
\hline C1_s1 & 81.4 & C2_s1_s2mean & 55.8 \\
\hline
\end{tabular}

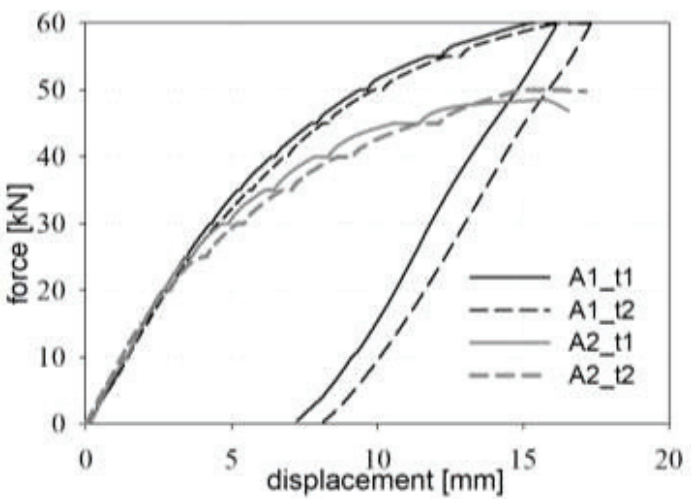

Fig. 7. Tensile force versus displacement - A type tests

Next, the force-controlled tests were carried out up to $60 \mathrm{kN}$ due to the steel base and up to $50 \mathrm{kN}$ due to the concrete base. The force held every $5 \mathrm{kN}$ in its waiting time equal to $120 \mathrm{~s}$. When the force reached the monitoring value $(5 \mathrm{kN}, 10 \mathrm{kN}$, etc.), displacement of the end plate (a point in Fig. 4) 
was measured. Displacement measurement of the middle point of the end plate was carried out at the start of a specific load level. When the force reached $60 \mathrm{kN}$ in a steel base and $50 \mathrm{kN}$ in a concrete foundation the aluminium brackets were unloaded after a specified waiting time. All Ctype specimens fulfilled the testing conditions, due to A and B types a single test leads to an end only.

Figures 7-9 show the diagrams of tensile force vs displacement of movable crosshead due to A, B, and $\mathrm{C}$ type tests. Displacements of movable crosshead (crosshead travel) under specific load are collected in Tables 4 and 5 for steel base and concrete foundation, respectively. Additionally, the displacement of the end plate middle point is shown in Tables 6 and 7 and in Figures 10-12.

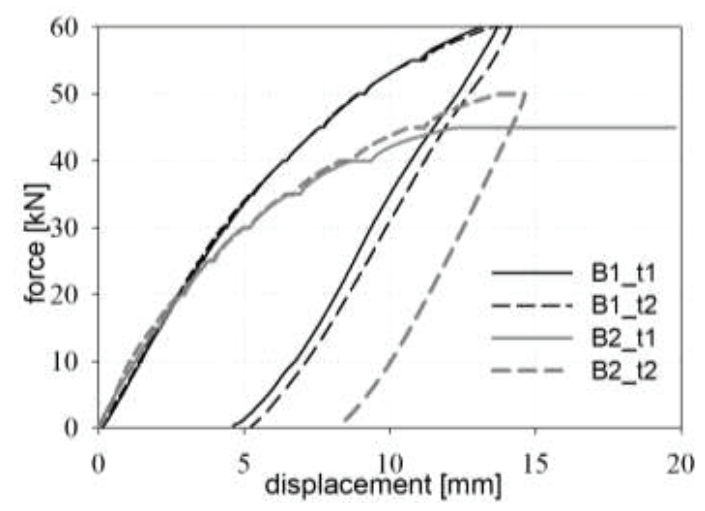

Fig. 8. Tensile force versus displacement - B type tests

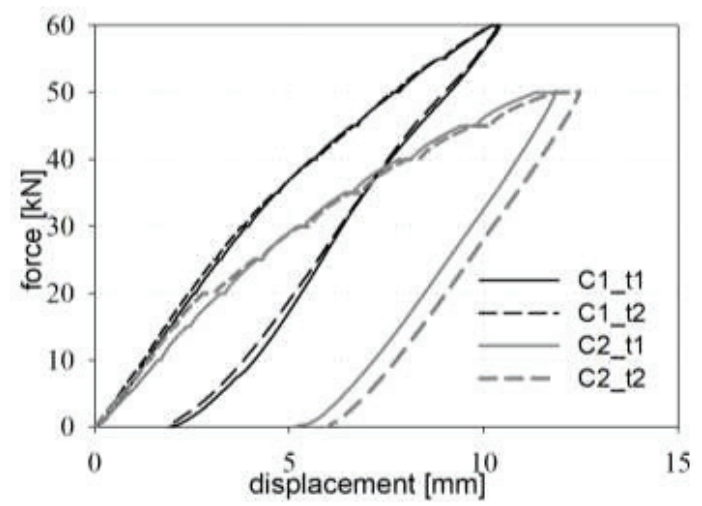

Fig. 9. Tensile force versus displacement $-\mathrm{C}$ type tests 


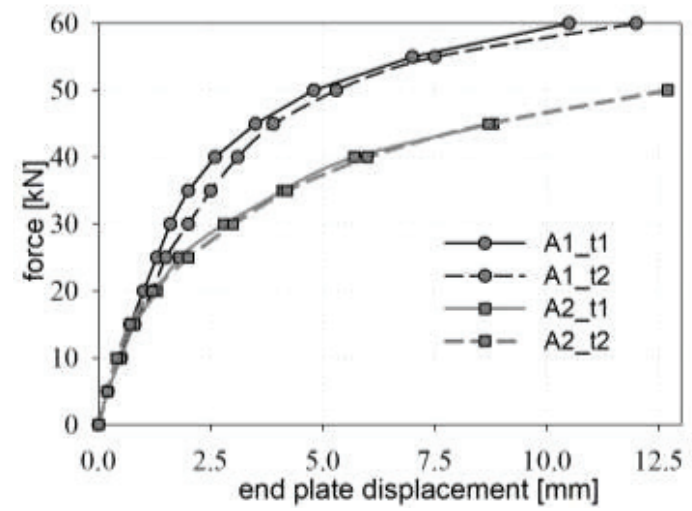

Fig. 10. Tensile force versus end plate displacement $-\mathrm{A}$ type tests

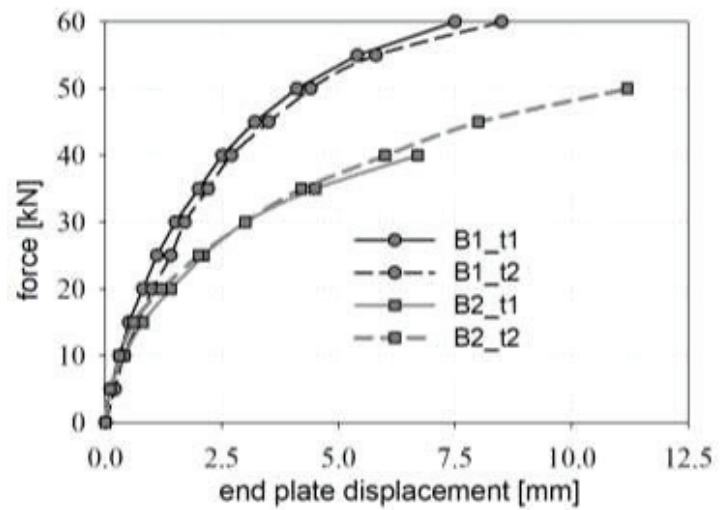

Fig. 11. Tensile force versus end plate displacement $-B$ type tests

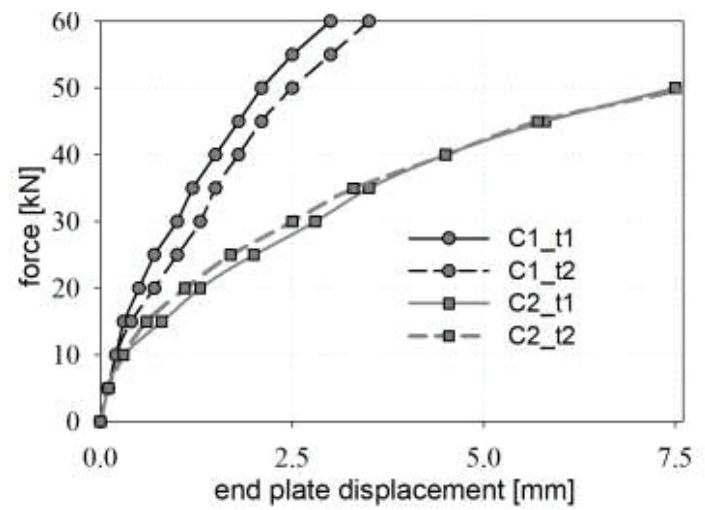

Fig. 12. Tensile force versus end plate displacement $-\mathrm{C}$ type tests 


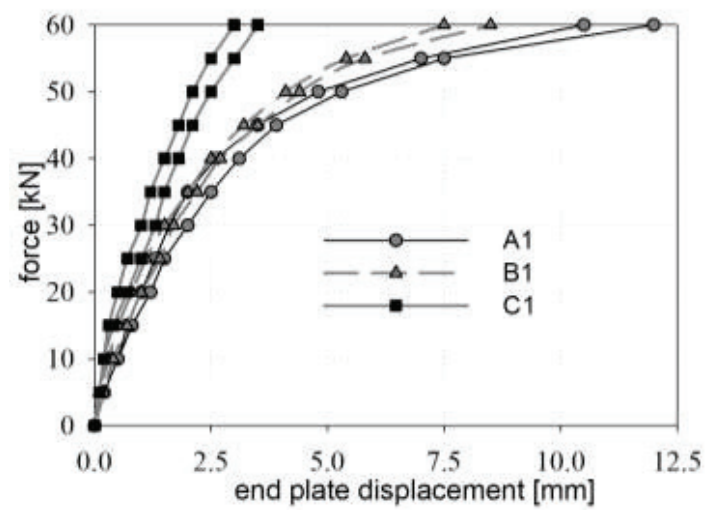

Fig. 13. Tensile force versus end plate displacement - steel base

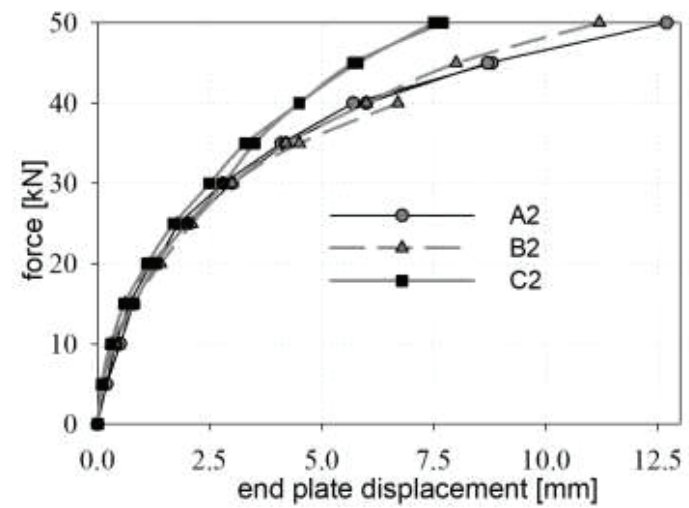

Fig. 14. Tensile force versus end plate displacement - concrete foundation

Table 4. Displacement [mm] of movable crosshead under specific load - steel base

\begin{tabular}{|c|c|c|c|c|c|c|c|c|c|}
\hline $\begin{array}{c}\text { force } \\
{[\mathrm{kN}]}\end{array}$ & A1_t & A1_t2 & A1mean & B1_t1 & B1_t2 & B1mean & C1_t1 & $\begin{array}{c}\text { C1_t2 } \\
\text { C1mea } \\
\text { n }\end{array}$ \\
\hline 5 & 0.78 & 0.79 & 0.78 & 0.83 & 0.77 & 0.80 & 0.79 & 0.65 & 0.72 \\
\hline 10 & 1.41 & 1.48 & 1.44 & 1.47 & 1.43 & 1.45 & 1.36 & 1.27 & 1.31 \\
\hline 15 & 2.03 & 2.13 & 2.08 & 2.14 & 2.09 & 2.11 & 1.96 & 1.83 & 1.89 \\
\hline 20 & 2.71 & 2.85 & 2.78 & 2.84 & 2.77 & 2.80 & 2.59 & 2.45 & 2.52 \\
\hline 25 & 3.47 & 3.65 & 3.56 & 3.59 & 3.49 & 3.54 & 3.25 & 3.11 & 3.18 \\
\hline 30 & 4.33 & 4.61 & 4.47 & 4.41 & 4.31 & 4.36 & 3.96 & 3.84 & 3.90 \\
\hline 35 & 5.30 & 5.71 & 5.50 & 5.34 & 5.27 & 5.30 & 4.73 & 4.69 & 4.71 \\
\hline 40 & 6.49 & 6.94 & 6.71 & 6.46 & 6.46 & 6.46 & 5.66 & 5.70 & 5.68 \\
\hline 45 & 7.92 & 8.32 & 8.12 & 7.74 & 7.71 & 7.72 & 6.71 & 6.75 & 6.73 \\
\hline 50 & 9.66 & 10.19 & 9.92 & 9.15 & 9.12 & 9.13 & 7.83 & 7.74 & 7.78 \\
\hline 55 & 12.19 & 12.86 & 12.52 & 11.05 & 11.18 & 11.11 & 9.01 & 8.96 & 8.98 \\
\hline 60 & 16.15 & 17.31 & 16.73 & 13.67 & 14.63 & 14.15 & 10.42 & 10.37 & 10.39 \\
\hline
\end{tabular}


Table 5. Displacement [mm] of movable crosshead under specific load - concrete base

\begin{tabular}{|c|c|c|c|c|c|c|c|c|c|}
\hline $\begin{array}{c}\text { Force } \\
{[\mathrm{kN}]}\end{array}$ & $\mathrm{A} 2$-t1 & A2_t2 & A2mean & B2_t1 & B2_t2 & $\begin{array}{c}\text { B2mea } \\
n\end{array}$ & C2_t1 & $\mathrm{C} 2 \_\mathrm{t} 2$ & C2mean \\
\hline 5 & 0.71 & 0.64 & 0.67 & 0.59 & 0.58 & 0.58 & 0.89 & 0.74 & 0.81 \\
\hline 10 & 1.43 & 1.26 & 1.34 & 1.29 & 1.12 & 1.20 & 1.69 & 1.41 & 1.55 \\
\hline 15 & 2.02 & 1.98 & 2.00 & 2.09 & 1.92 & 2.00 & 2.45 & 2.07 & 2.26 \\
\hline 20 & 2.71 & 2.89 & 2.80 & 2.97 & 2.89 & 2.93 & 3.35 & 3.08 & 3.21 \\
\hline 25 & 3.65 & 4.15 & 3.90 & 3.93 & 3.96 & 3.94 & 4.31 & 4.28 & 4.29 \\
\hline 30 & 4.91 & 5.44 & 5.17 & 5.22 & 5.21 & 5.21 & 5.39 & 5.51 & 5.45 \\
\hline 35 & 6.47 & 7.06 & 6.76 & 6.93 & 6.73 & 6.83 & 6.65 & 6.84 & 6.74 \\
\hline 40 & 8.32 & 9.16 & 8.74 & 9.38 & 8.73 & 9.05 & 8.14 & 8.34 & 8.24 \\
\hline 45 & 11.46 & 12.13 & 11.79 & $21.0 \mathrm{D} 3$ & 11.20 & - & 9.80 & 10.16 & 9.98 \\
\hline 50 & 19.1D1 & $20.8 \mathrm{D} 2$ & - & & 14.63 & - & 11.85 & 12.46 & 12.15 \\
\hline
\end{tabular}

Rupture forces: D1 $=48.45 \mathrm{kN}$; D2 $=50 \mathrm{kN}$; $3=45.07 \mathrm{kN}$

Table 6. Displacement [mm] of end plate middle point under specific load - steel base

\begin{tabular}{|c|c|c|c|c|c|c|c|c|c|}
\hline $\begin{array}{c}\text { force } \\
{[\mathrm{kN}]}\end{array}$ & A1_t1 & A1_t2 & A1mean & B1_t1 & B1_t2 & B1mean & C1_t1 & C1_t2 & C1mean \\
\hline 5 & 0.2 & 0.2 & 0.2 & 0.1 & 0.2 & 0.15 & 0.1 & 0.1 & 0.1 \\
\hline 10 & 0.5 & 0.5 & 0.5 & 0.3 & 0.4 & 0.35 & 0.2 & 0.2 & 0.2 \\
\hline 15 & 0.7 & 0.8 & 0.75 & 0.5 & 0.7 & 0.6 & 0.3 & 0.4 & 0.35 \\
\hline 20 & 1.0 & 1.2 & 1.1 & 0.8 & 1.0 & 0.9 & 0.5 & 0.7 & 0.6 \\
\hline 25 & 1.3 & 1.5 & 1.4 & 1.1 & 1.4 & 1.25 & 0.7 & 1.0 & 0.85 \\
\hline 30 & 1.6 & 2.0 & 1.8 & 1.5 & 1.7 & 1.6 & 1.0 & 1.3 & 1.15 \\
\hline 35 & 2.0 & 2.5 & 2.25 & 2.0 & 2.2 & 2.1 & 1.2 & 1.5 & 1.35 \\
\hline 40 & 2.6 & 3.1 & 2.85 & 2.5 & 2.7 & 2.6 & 1.5 & 1.8 & 1.65 \\
\hline 45 & 3.5 & 3.9 & 3.7 & 3.2 & 3.5 & 3.35 & 1.8 & 2.1 & 1.95 \\
\hline 50 & 4.8 & 5.3 & 5.05 & 4.1 & 4.4 & 4.25 & 2.1 & 2.5 & 2.3 \\
\hline 55 & 7.0 & 7.5 & 7.25 & 5.4 & 5.8 & 5.6 & 2.5 & 3.0 & 2.75 \\
\hline 60 & 10.5 & 12.0 & 11.25 & 7.4 & 8.5 & 7.95 & 3.0 & 3.5 & 3.25 \\
\hline
\end{tabular}

Table 7. Displacement [mm] of end plate middle point under specific load - concrete base

\begin{tabular}{|c|c|c|c|c|c|c|c|c|c|}
\hline $\begin{array}{c}\text { Force } \\
{[\mathrm{kN}]}\end{array}$ & A2_t1 & A2_t2 & A2mean & B2_t1 & B2_t2 & $\begin{array}{c}\text { B2mea } \\
n\end{array}$ & C2_t1 & C2_t2 & C2mean \\
\hline 5 & 0.2 & 0.2 & 0.2 & 0.1 & 0.1 & 0.1 & 0.1 & 0.1 & 0.1 \\
\hline 10 & 0.5 & 0.4 & 0.45 & 0.4 & 0.3 & 0.35 & 0.3 & 0.3 & 0.3 \\
\hline 15 & 0.8 & 0.7 & 0.75 & 0.8 & 0.6 & 0.7 & 0.8 & 0.6 & 0.7 \\
\hline 20 & 1.3 & 1.2 & 1.25 & 1.4 & 1.2 & 1.3 & 1.3 & 1.1 & 1.2 \\
\hline 25 & 1.8 & 2.0 & 1.9 & 2.1 & 2.0 & 2.05 & 2.0 & 1.7 & 1.85 \\
\hline 30 & 2.8 & 3.0 & 2.9 & 3.0 & 3.0 & 3.0 & 2.8 & 2.5 & 2.65 \\
\hline 35 & 4.1 & 4.2 & 4.15 & 4.5 & 4.2 & 4.35 & 3.5 & 3.3 & 3.45 \\
\hline 40 & 5.7 & 6.0 & 5.85 & 6.7 & 6.0 & 6.35 & 4.5 & 4.5 & 4.5 \\
\hline 45 & 8.8 & 8.7 & 8.75 & $-\mathrm{D} 3$ & 8.0 & - & 5.8 & 5.7 & 5.75 \\
\hline 50 & $-\mathrm{D} 1$ & $12.7 \mathrm{D} 2$ & - & & 11.2 & - & 7.5 & 7.7 & 7.6 \\
\hline
\end{tabular}




\section{DisCuSSION AND CONCLUSIONS}

The investigation is aimed at assessing mechanical properties of aluminium brackets strengthened by washers and straps (cover plates) on steel base and concrete foundations. The paper supplements and develops former investigations carried out by Ambroziak et al. [1], it may provide scientists, engineers, and designers with an experimental and theoretical basis in the field of mechanical properties of strengthened aluminium brackets. Based on the performed laboratory tests the following conclusions may be drawn:

- Rupture forces of the aluminium bracket on a steel base (see Fig. 6 and Table 3) rise up (36\% and 15\%) while applying the washer with an outer diameter about $3 \mathrm{~d}$ (large washer) and additional aluminium cover plates (straps). On the other hand, while an aluminium bracket is tested on a concrete foundation (see Fig. 6 and Table 3) insignificant increase of rupture forces (about 5\%) is observed. Rupture forces are determined by means of bearing capacity of bolt anchors. It should be noted that permissible loads for bolt anchoring are affected by a great number of factors (see e.g. Ambroziak and Solarczyk [2]).

- The displacements of the end plate middle point of the aluminium bracket with cover plates (C type) under tensile loads on a steel plate (see Fig. 13 and table 6) clearly exhibit the increase in stiffness and decrease in displacements, comparing the A and B type specimens. On the other hand, when aluminium brackets on concrete foundations were tested the differences were apparent in the case of higher loads (see Fig. 14 and table 7). The aluminium bracket with cover plates ( $\mathrm{C}$ type) shows an increase in stiffness and decrease in displacement over the tensile load of $25 \mathrm{kN}$.

- The flexibility of anchoring strongly affects the increase of the end plate middle point displacement and movable crosshead displacement (compare Figs. 7-12). It should be noted that flexibility of anchoring on a steel base is restrained by stretching the steel bolts only (see Fig. 5). When the torque-controlled expansion anchors are applied additional slip in the anchoring is observed. The bolt anchor manufacturers' guidelines specify a displacement value of bolt anchor under tensile load (see table 2, factor $\delta_{N \infty} \mathrm{mm} / \mathrm{kN}$ ). The design of bolt anchoring should be intended not only to fulfil loading conditions but also to compare their flexibility (slip in anchoring due to loads).

- Laboratory tests on rigid metal profiles (steel plates) indicate different values of the middle point displacement and movable crosshead displacement. The guidelines for determining the 
resistance of aluminium brackets on rigid metal profile (see e.g. the ETAG 034 guideline [6]) should be verified. The laboratory tests should be carried out on a concrete substrate with specified anchoring systems to determine proper mechanical behaviour of aluminium brackets.

The paper is dedicated to the engineers performing structural design of aluminium brackets to fasten lightweight curtain walls to building facilities. It provides the information on mechanical properties under vertical loads of aluminium brackets and the possibilities of its strengthening. The results encourage the author to continue the research, on the basis of performing laboratory tests with biaxial loads (vertical and horizontal), complemented by cyclic and rheological tests in order to assess the long-time properties of aluminium brackets strengthened by additional aluminium cover plates (straps) or stainless steel large washer.

\section{REFERENCES}

1. A. Ambroziak, M.T. Solarczyk, A. Biegus, "Numerical and analytical investigation of aluminium bracket strengthening." Archives of Civil Engineering, 64(2): 37-54, 2018. DOI: 10.2478/ace-2018-0015

2. A. Ambroziak, M.T. Solarczyk, "Incorrect solutions in the field of anchoring in civil engineering." Materiały Budowlane, 5: 18-19, 2017. DOI: 10.15199/33.2017.05.05

3. P. Zoetemeijer, "A design method for the tension side of statically loaded, bolted beam-to-column connections.” Heron 20(1) 1974, Delft University, Delft, Holland.

4. R.S. Nair, P.C. Birkemoe, W.H. Munse, "High Strength Bolts Subject to Tension and Prying." Journal of the Structural Division, ASCE, 100(2): 351-372, 1974.

5. CEN (European Committee for Standardization) "Aluminium and aluminium alloys. Extruded rod/bar, tube and profiles. Mechanical properties.” EN 755-2, 2016 Brussels, Belgium.

6. EOTA (European Organisation for Technical Assessment) "Guideline for European Technical Approval of kits for external wall claddings part II: Cladding kits comprising cladding components, associated fixings, subframe and possible insulation layer." ETAG 034, 2012, Brussels, Belgium.

7. CEN (European Committee for Standardization) "Concrete - Specification, performance, production and conformity." EN 206+A1, 2013, Brussels, Belgium.

8. K. Kazmierczak, "Review of curtain walls, focusing on design problems and solutions." Building Enclosure Science \& Technology, Portland, April 12-14, BEST2 - Design and Rehabilitation - Session EE4-1, 1-20, 2010. https://cdn.ymaws.com/www.nibs.org/resource/resmgr/BEST/BEST2_008_EE4-1.pdf

9. J. Č. Tovarović, N. Šekularac, J. Ivanović-Šekularac, "Problems Associated With Curtain Walls." Structural Engineering International, 27(3), 413-417, 2017.

\section{LIST OF FIGURES AND TABLES:}

Fig. 1. View on fixed aluminium brackets in mullion-transom wall system

Rys. 1. Widok na zamocowanie konsoli aluminiowej w systemie słupowo-ryglowym

Fig. 2. View and cross-section of analysed aluminium bracket

Rys. 2. Widok i przekroje analizowanej konsoli aluminiowej

Fig. 3. Analysed aluminium bracket with plain washers and cover plates (straps)

Rys. 3. Analizowana konsola z testowanymi podkładkami i nakładkami (stemplami)

Fig. 4. Laboratory test stands for steel and concrete bases 
Rys. 4. Stanowisko badawcze na podłożu stalowym i betonowym

Fig. 5. Damaged aluminium brackets after tensile tests

Rys. 5. Zniszczone konsole aluminiowe po badaniach

Fig. 6. Tensile force versus displacement up to rupture of aluminium bracket

Rys. 6. Wykresy siła rozciągająca-przemieszczenie do zniszczenia konsoli aluminiowej

Fig. 7. Tensile force versus displacement - A type tests

Rys. 7. Wykresy siła rozciągająca-przemieszczenie - testy typ A

Fig. 8. Tensile force versus displacement $-\mathrm{B}$ type tests

Rys. 8. Wykresy siła rozciągająca-przemieszczenie - testy typ B

Fig. 9. Tensile force versus displacement $-\mathrm{C}$ type tests

Rys. 9. Wykresy siła rozciągająca-przemieszczenie - testy typ C

Fig. 10. Tensile force versus end plate displacement - A type tests

Rys. 10. Wykresy siła rozciągająca-przemieszczenie blachy podstawy-testy typ A

Fig. 11. Tensile force versus end plate displacement - B type tests

Rys. 11. Wykresy siła rozciągająca-przemieszczenie blachy podstawy- testy typ B

Fig. 12. Tensile force versus end plate displacement $-\mathrm{C}$ type tests

Rys. 12. Wykresy siła rozciągająca-przemieszczenie blachy podstawy- testy typ C

Fig. 13. Tensile force versus end plate displacement - steel base

Rys. 13. Wykresy siła rozciągająca-przemieszczenie blachy podstawy-podłoże stalowe

Fig. 14. Tensile force versus end plate displacement - concrete foundation

Rys. 14. Wykresy siła rozciągająca-przemieszczenie blachy podstawy- podłoże betonowe

Tab. 1. Mechanical properties of EN AW-6060 T66 according to EN 755-2 [5]

Tab. 1. Właściwości mechaniczne stopu EN AW-6060 T66 zgodnie z EN 755-2 [5]

Tab. 2. Technical data of a single anchor in non-cracked normal concrete

Tab. 2. Dane techniczne pojedynczego zakotwienia mechanicznego w niespękanym betonie

Tab. 3. Rupture forces $[\mathrm{kN}]$ of aluminium bracket

Tab. 3. Siły niszczące $[\mathrm{kN}]$ konsolę aluminiową

Tab. 4. Displacement [mm] of movable crosshead under specific load - steel base

Tab. 4. Przemieszczenia [mm] głowicy dla określonych obciążeń - podłoże stalowe

Tab. 5. Displacement [mm] of movable crosshead under specific load - concrete base

Tab. 5. Przemieszczenia [mm] głowicy dla określonych obciążeń - podłoże betonowe

Tab. 6. Displacement [mm] of end plate middle point under specific load - steel base

Tab. 6. Przemieszczenia [mm] blachy czołowej dla określonych obciążeń - podłoże stalowe

Tab. 7. Displacement [mm] of end plate middle point under specific load - concrete base

Tab. 7. Przemieszczenia [mm] blachy czołowej dla określonych obciążeń - podłoże betonowe 


\section{WŁAŚCIWOŚCI MECHANICZNE WZMOCNIONYCH KONSOL ALUMINIOWYCH}

Keywords: konsole aluminiowe, właściwości mechaniczne, EN AW-6060 T66, wzmocnienie konsoli

\section{STRESZCZENIE:}

Przedmiotem przedstawionych w artykule badań są konsole aluminiowe, które są stosowane jako łączniki fasad słupowo-ryglowych z konstrukcją budynku. Konsole wykonano ze stopu aluminium AW-6060 wg PN-EN 573-3:2004, odmiana T66 wg PN-EN 515:1996. W pracy badano wpływ zastosowania w miejscu kotwieni konsol aluminiowych zwykłej stalowej podkładki (typ A), powiększonej stalowej podkładki (typ B) oraz aluminiowych nakładek (tzw. stempli, typ C). Konsole aluminiowe kotwiono do podłoża stalowego i betonowego wykorzystując śruby lub kotwy mechaniczne. Zastosowanie dwóch typów podłoża, do którego kotwiono konsole aluminiowe, umożliwiło ocenę wpływu podatności kotwienia mechanicznego na nośności i sztywności wzmacnianych konsol aluminiowych. Wyniki badań wskazują iż zastosowanie aluminiowych nakładek, usytuowanych pod nakrętkami śrub łączących je $\mathrm{z}$ konstrukcją budynku, zwiększa sztywności konsol aluminiowych. Nakładki wzmacniają lokalnie blachy czołowe konsol. Ich zadaniem konstrukcyjnym jest m.in. zmniejszenie ramienia „zginania” $c$ oraz zwiększenie sztywności giętnej blachy czołowej konsoli.

Artykuł uzupełnia i rozwija badania prowadzone przez Ambroziaka i innych [1]. Wykonane i opisane badania stanowią podstawę do szczegółowego opisania właściwości mechanicznych testowanych rozwiązań wzmacniania konsol aluminiowych. Nośność konsoli aluminiowej zamocowanej do stalowej płyty wzrasta (od 15\% do 36\%) po zastosowaniu podkładek powiększonych i dodatkowych nakładek aluminiowych. W przypadku kotwienia konsoli aluminiowej do zbrojonego elementu betonowego obserwuje się nieznaczny wzrost nośności (około 5\%). W tym przypadku nośność konsoli aluminiowej determinowana jest nośnością zastosowanego kotwienia mechanicznego. Przemieszczenia środkowego punktu blachy czołowej konsoli aluminiowej z nakładkami (typu C) zamocowanej do podłoża stalowego pod obciążeniem rozciągającym wykazuje wzrost sztywności i zmniejszenie przemieszczeń w porównaniu z typami A i B. Dla konsol aluminiowych kotwionych do podłoża betonowego efekt zwiększenia sztywności z zastosowaniem nakładek widoczny jest w przypadku wyższych wartości obciążeń.

Podatność kotwienia silnie wpływa na zwiększenie przemieszczeń konsoli aluminiowej (w tym punktu środkowego blachy czołowej) i utratę nośności konsoli. Podatność zamocowania konsoli do stalowej płyty ograniczona jest do wydłużenia się stalowych śrub. W przypadku zastosowania kotew rozprężnych $\mathrm{z}$ kontrolowanych momentem dokręcenia obserwuje się dodatkowy ich poślizg w zakotwieniu. Wytyczne techniczne producentów kotew określają wartość tych przemieszczeń. Prawidłowy proces projektowania zakotwienia mechanicznego w przypadku konsol nie powinien ograniczać się jedynie do spełnienia wymagań nośności łączników, ale także do ograniczenia ich podatności (ograniczenia poślizgu w kotwieniu pod wpływem obciążeń). Do prawidłowej oceny nośności sztywności konsol aluminiowych badania mechaniczne należy prowadzić na podłożu betonowym z zastosowaniem projektowanego systemu kotwienia.

Received 31.07.2019

Revised 24.10.2019 